\title{
Experimental study of an organic Rankine cycle system with radial
} inflow turbine and R123

\author{
Long Shao ${ }^{1}$, Jie Zhu ${ }^{2}$, Xiangrui Meng ${ }^{1,3^{*}}$, Xinli Wei ${ }^{1,3^{*}}$, Xinling Ma ${ }^{1,3}$ \\ ${ }^{1}$ School of chemical engineering and energy, Zhengzhou University, \\ Zhengzhou, 450001, China \\ ${ }^{2}$ Fluids \& Thermal Engineering Research Group, Faculty of Engineering, University of \\ Nottingham, Nottingham, NG7 2RD, UK \\ ${ }^{3}$ Department of Process Equipment \& Control Engineering, Zhengzhou University, 450001 \\ Zhengzhou, China
}

\begin{abstract}
A new micro radial inflow turbine is developed for a mini organic Rankine cycle (ORC) system in this study. With R123 as the working fluid, the turbine operational characteristics and performance are investigated by experiments. Based on the experimental data, the maximum rotational speed of the radial inflow turbine reaches $53564 \mathrm{r} / \mathrm{min}$, and the maximum output power of the turbine is $3.386 \mathrm{~kW}$ and the maximum electric power reaches $1.884 \mathrm{~kW}$. When the turbine rotational speed is $34586 \mathrm{r} / \mathrm{min}$, the system isentropic and electromechanical efficiencies achieve the maximum values of $83.6 \%$ and $65.3 \%$ respectively. Both the turbine isentropic and thermal efficiencies increase with the heat source temperature.
\end{abstract}

Keyword: organic Rankine cycle; radial inflow turbine; isentropic efficiency; thermal efficiency

\section{Introduction}

As a widely used energy recovery technology, the organic Rankine cycle (ORC) can recover low-grade heat with some advantages such as high efficiency, low pollution, as well as simple structure ${ }^{[1]}$. The ORC is particularly suitable for the system with low-grade heat source, such as below $350^{\circ} \mathrm{C}$. The different types of heat source can be recovered by ORC system under various operating conditions. Besides industrial waste heat, some other low-grade heat sources can also be converted into electricity with the ORC, such as solar thermal, geothermal, biomass, engine waste heat and ocean thermal energy ${ }^{[2]}$. 
Since the late 1970s and early 1980s, a great deal of attention has been paid to the ORC technology ${ }^{[3]}$. The radial inflow turbine is adopted as the expander in ORC with low temperature heat source, thus its theory study is a hot issue. Kim et al. ${ }^{[4]}$ proposed a design method to develop radial inflow turbine for ORC, their results show that the incidence angle to the rotor blades and rotation speed have a remarkable impact on the turbine efficiency. Based on the thermodynamic analysis of ORC system and the aerodynamic design of the turbine, $\mathrm{Li}$ et al. ${ }^{[5]}$ found that the shock wave can be controlled at the high expansion ratio in the nozzle. Pan et al. ${ }^{[6]}$ adopted the internal efficiency of optimal radial flow turbine instead of isentropic efficiency, and found internal efficiency depends on expansion ratio. In the application of a heavy-duty off-road diesel engine, Costall et al. ${ }^{[7]}$ presented a design method for radial turbine expander, and found that the turbo expander for ORC is practical even though at a small scale. Fiaschi et al. ${ }^{[8]}$ compared the effects of various working fluids on the cycle thermodynamics, flow losses and turbo-expander efficiencies. Aiming at performing the initial design of a turbo-expander which satisfies different system requirements, Capata et al. ${ }^{[9]}$ carried out a thermo-mechanical study to check structural tension and possible displacement. Ricardo et al. ${ }^{[10]}$ studied the integration of humid air micro-turbine and an ORC, their results show that the integration is a promising solution for the distributed power generation because of its relative simplicity and low cost.

The expander of ORC is more compact than steam turbine since the density of the organic working fluid is higher than that of steam. A number of experimental works are conducted for the proposed systems, with the aim of improving the performance of expander and efficiency of the cycle. Li et al. ${ }^{[11]}$ investigated the effects of mass flow rate of working fluid on the ORC performance, in the system an electric heater being a heat source, R123 being working fluid, and a single-stage axial flow turbine being the expander. When evaporation temperature is constant, the turbine inlet pressure and rotational speed increase with the mass flow rate. Wang et al. ${ }^{[12-13]}$ conducted an experimental study to investigate the performance of a low-temperature solar Rankine cycle with R245fa as the working fluid. Yamamoto et al. ${ }^{[14]}$ built ORC system integrated with a radial flow turbine to investigate the performance of the turbine with R123 as the working fluid. The turbine output power initially increases and then decreases with its rotational speed, therefore the maximum electric power of the system exists at the optimized rotational speed. Kang et al. ${ }^{[15]}$ developed an ORC system with a radial flow turbine directly connected to a high-speed generator to study the effects of evaporation temperature on the turbine efficiency, working fluid flow rate and electric power. Their results show that the turbine and thermal efficiencies increase with the evaporation temperature. Fiashi et al. ${ }^{[16]}$ improved radial 
turbo-expander design with two different shapes of impeller blades and evaluated the influences of different working fluids, their results indicate that the turbo-expander with R134a presents the highest efficiency and the efficiency can be increased by 1.5 to $2.5 \%$ with backswept bladed impellers.

Even though many investigations have been carried out for radial flow turbine in ORC system, only few research works have studied the effect of cold source flow rate on the expander performance. In this experimental study, the efficiency of the radial inflow turbine is explored, and the influences of heat source temperature and working fluid flow rate on the system performance are clarified. The impact of cooling water on the turbine pressure ratio and output power is also presented.

\section{Experimental Apparatus}

\subsection{Design of radial inflow turbine}

The key component of the experimental ORC system is a radial inflow turbine which has many advantages, such as large enthalpy drop in a single stage, high efficiency, compact structure, and low manufacturing cost. So it has been widely applied to aircraft engines, cryogenic air separation units, and turbochargers. A radial inflow turbine mainly consists of inward flow volute, impeller, and deflector. In order to develop the radial inflow turbine, its thermodynamic calculation is essential, many parameters are involved in this process and some parameters interact with each other. The calculation is performed by the Visual Basic, which is associated with the weather conditions in Zhengzhou, China, under an arithmetic mean temperature of $20^{\circ} \mathrm{C}$. Table 1 shows the main parameters of the radial inflow turbine.

The impeller flow passage is specially designed by geometric modelling, the air-powered straight impeller blades are selected as the guide vanes. A configuration of the single volute inlet is adopted for the radial turbine, in which the cross-sectional area decreases uniformly along with the direction of air flow in a helical pipe. Fig. 1 illustrates the specially designed radial inflow turbine and the labyrinth seal. The prototype is a turbo-machine which can rotate at high speed and is suitable for power generation. Combined with self-sealed ceramic rolling bearings, a labyrinth seal is applied for the prototype to prevent fluid leakage at the surface of shaft end.

\subsection{Description of the experimental ORC system}


The experimental system consists of an electric heater, an evaporator, a condenser, a diaphragm pump, a radial inflow turbine, a generator and electrical loads. The system working fluid is R123. Fig. 2 shows the experimental ORC system powered by low-temperature waste heat, and Fig. 3 indicates its T-S diagram. Process 1-2: The heat transfer oil is heated by the electric heater, then the heat is transferred from the oil to the working fluid R123 for evaporation in the evaporator. Process3-4: The vapour of R123 flows into the turbine which drives a three-phase permanent magnet synchronous generator. Process5-6: The exhaust vapour at the turbine outlet is condensed in the condenser, and then the liquid R123 flows into the storage tank. Process 7-8: The liquid R123 is pumped into the evaporator again by the working fluid pump, thus another cycle starts.

Fig. 4 shows the experimental platform. A Coriolis mass flow meter is used for measuring the mass flow rate of the working fluid, the temperature and pressure of each unit are measured by the correspondent transducers. The data from the Coriolis mass flow meter and the transducers are recorded by an Agilent data acquisition system. The generator frequency and power output are monitored as well. The specifications of the instruments are listed in Table 2.

In order to assess the performances of the radial inflow turbine and ORC system, the experimental tests are carried out by changing the working fluid flow rate and its temperature. An experiment related to the cold source temperature on the turbine performance is also conducted. The parameters of experimental operating condition are shown in Table 3. The thermodynamic and physical properties of the working fluid are obtained with RefProp9 according to the experimental condition.

\section{Main Parameters and Experimental Procedure}

\subsection{Main parameters}

In the experimental system, the pump power $W_{\mathrm{P}}(\mathrm{kW})$ is calculated by Equation (1).

$$
W_{p}=q_{m}\left(h_{8}-h_{7}\right)
$$


where, $q_{\mathrm{m}}$ is mass flow rate of the working fluid, $\mathrm{kg} / \mathrm{s} ; h_{7}$ is enthalpy of the working fluid at the pump inlet, $\mathrm{kJ} / \mathrm{kg}$; $h_{8}$ is enthalpy of the working fluid at the pump outlet, $\mathrm{kJ} / \mathrm{kg}$.

Heat transfer rate $Q_{21}(\mathrm{~kW})$ in the evaporator is obtained by Equation (2).

$$
Q_{21}=q_{m}\left(h_{2}-h_{1}\right)
$$

where, $h_{1}$ is enthalpy of the working fluid at the evaporator inlet, $\mathrm{kJ} / \mathrm{kg} ; h_{2}$ is enthalpy of the working fluid at the evaporator outlet, $\mathrm{kJ} / \mathrm{kg}$.

Heat $Q_{56}(\mathrm{~kW})$ released by the working fluid in the condenser is calculated by Equation (3).

$$
Q_{56}=q_{m}\left(h_{5}-h_{6}\right)
$$

where, $h_{5}$ is enthalpy of the working fluid at the condenser inlet, $\mathrm{kJ} / \mathrm{kg} ; h_{6}$ is enthalpy of the working fluid at the condenser outlet, $\mathrm{kJ} / \mathrm{kg}$.

The turbine output power $\mathrm{W}_{\mathrm{T}}(\mathrm{kW})$ is calculated by Equation (4).

$$
W_{\mathrm{T}}=q_{m}\left(h_{3}-h_{4}\right)
$$

where, $h_{3}$ is enthalpy of the working fluid at the turbine inlet, $\mathrm{kJ} / \mathrm{kg} ; h_{4}$ is enthalpy of the working fluid at the turbine outlet, $\mathrm{kJ} / \mathrm{kg}$.

The isentropic expansion power of the turbine $W_{\mathrm{T}, \mathrm{S}}(\mathrm{kW})$ is obtained by Equation (5).

$$
W_{\mathrm{T}, \mathrm{S}}=q_{m}\left(h_{3}-h_{4 \mathrm{~s}}\right)
$$

where, $h_{4 \mathrm{~s}}$ is isentropic enthalpy of the working fluid at the turbine outlet, $\mathrm{kJ} / \mathrm{kg}$.

The isentropic efficiency $\eta_{\mathrm{s}}$ of the turbine is defined as the ratio of the actual expansion power done by the turbine to the isentropic expansion power that can be done by the turbine. It indicates how well a turbine would perform, which is calculated by Equation (6).

$$
\eta_{\mathrm{s}}=\frac{W_{\mathrm{T}}}{W_{\mathrm{T}, \mathrm{S}}}=\frac{h_{3}-h_{4}}{h_{3}-h_{4 \mathrm{~s}}}
$$

As a dynamic system for energy recovery, the actual power output is the key indicator of the system performance. The electromechanical efficiency $\eta_{\mathrm{M}}$ is defined as the ratio of the generator power output to the work done by the turbine, which is calculated by Equation (7). 


$$
\eta_{\mathrm{M}}=\frac{P_{\mathrm{e}}}{W_{\mathrm{T}}}=\frac{P_{\mathrm{e}}}{q_{m}\left(h_{3}-h_{4}\right)}
$$

where, $P_{\mathrm{e}}$ is electric power output of the generator, $\mathrm{kW}$.

The thermal efficiency $\eta_{\mathrm{t}}$ is defined as the ratio of the actual radial turbine work output to the heat absorbed by the working fluid in the evaporator, and calculated by Equation (8).

$$
\eta_{\mathrm{t}}=\frac{W_{\mathrm{T}}-W_{\mathrm{P}}}{Q_{21}}=\frac{\left(h_{3}-h_{4}\right)-\left(h_{8}-h_{7}\right)}{h_{2}-h_{1}}
$$

\subsection{Experimental procedure}

The first step of experiment procedure is to assess the turbine performance variation with the heat source temperature. The temperature of heat source varies from $110^{\circ} \mathrm{C}$ to $140^{\circ} \mathrm{C}$, and the working fluid flow rates are set as $0.17 \mathrm{~kg} / \mathrm{s}$ and $0.22 \mathrm{~kg} / \mathrm{s}$ respectively. The second step is to identify the turbine performance variation with its rotation speed. The available heat source temperatures, namely $110^{\circ} \mathrm{C}, 120^{\circ} \mathrm{C}$ and $130^{\circ} \mathrm{C}$, are used in this step. In order to obtain different rotational speeds, the flow rate of R123 is changed step by step, ranging from $0.115 \mathrm{~kg} / \mathrm{s}$ to $0.253 \mathrm{~kg} / \mathrm{s}$. The last step is to investigate the cold source influence by changing the mass flow rate of the cooling water. The temperatures of the heat source and cooling water are $130^{\circ} \mathrm{C}$ and $15.4^{\circ} \mathrm{C}$, respectively in this step. The flow rate of the cooling water varies from $0.27 \mathrm{~kg} / \mathrm{s}$ to $1.11 \mathrm{~kg} / \mathrm{s}$ when the flow rate of R123 is fixed.

\section{Results and Discussion}

\subsection{Effects of heat source temperature}

Heat source temperature is an important external factor affecting the radial turbine performance. Fig.5 demonstrates the impact of the heat source temperature on turbine inlet and outlet temperatures at a mass flow rate of $0.22 \mathrm{~kg} / \mathrm{s}$. It can be seen that the turbine's inlet and outlet temperatures increase gradually with the heat source temperature. The heat source temperature also has the influence on evaporator's outlet temperature which is related to the turbine's inlet temperature. It is noticed that there are some temperature drops in the turbine's expansion process as indicated by its outlet temperature. However, the outlet temperature still increases with the heat 
source temperature in the whole process. Fig. 6 illustrates the impact of heat source temperature on the turbine inlet and outlet pressures at the same mass flow rate of $0.22 \mathrm{~kg} / \mathrm{s}$. With heat source temperature increasing, the inlet and outlet pressures gradually increase as well. The increase rate of inlet pressure is higher than the outlet's. This is because that the inlet pressure is directly related to the evaporator outlet state and physical property of the working fluid.

\subsection{Effects of working fluid flow rate}

Fig. 7 shows the turbine inlet state variation with the working fluid flow rate. In the experiment, the mass flow rate of the working fluid varies from $0.115 \mathrm{~kg} / \mathrm{s}$ to $0.253 \mathrm{~kg} / \mathrm{s}$ by adjusting the stroke of the pump. The turbine inlet pressure increases with the mass flow rate, but the superheat of working fluid decreases. At a constant flow rate, the working fluid pressure at inlet increase with inlet temperature while the superheat decreases, which could be related to the thermodynamic properties of R123. Fig. 8 displays the effects of the mass flow rate on the system pressure drop and thermal efficiency. The system pressure drop is pressure difference between the radial turbine inlet and the condenser outlet, and it is related to the system thermal efficiency. The increase in the mass flow rate of the working flow causes the rises of the system pressure drop and thermal efficiency. In the experiments, the maximum system thermal efficiency is $5.7 \%$.

\subsection{Effects of turbine rotational speed}

Fig. 9 indicates the influences of the turbine rational speed on the temperature and enthalpy drops in the turbine. The different rotational speeds of the turbine are obtained by altering the working fluid mass flow rate through a hydraulic diaphragm pump. The rotational speed increases from 20000r/min to $54000 \mathrm{r} / \mathrm{min}$ approximately as the mass flow rate varies from $0.115 \mathrm{~kg} / \mathrm{s}$ to $0.253 \mathrm{~kg} / \mathrm{s}$. The enthalpy drop in the turbine increases mildly with the rotational speed but the temperature drops increase greatly. The enthalpy drop results in the turbine output power rise. At a fixed rotational speed, the temperature and enthalpy drops at a high inlet temperature are bigger than those at a low inlet temperature. The maximum temperature and enthalpy drops are $22^{\circ} \mathrm{C}$ and $13.7 \mathrm{~kJ} / \mathrm{kg}$ respectively at the rotational speed of $53481 \mathrm{r} / \mathrm{min}$ and the inlet temperature of $130^{\circ} \mathrm{C}$. 
Fig. 10 presents the effects of the turbine rotational speed on its isentropic efficiency and output power at a fixed inlet temperature. The isentropic efficiency initially increases with the rotational speed, however with further increase in the rotational speed, the isentropic efficiency drops after reaching a maximum value. So an optimum rotational speed exists under this situation, it can be obtained by changing the mass flow rate during the experiment. It can be seen from Fig. 10 that the optimum rotational speed increases with the inlet temperature. For example, the optimum rational speed is about $32900 \mathrm{r} / \mathrm{min}$ at inlet temperature of $110^{\circ} \mathrm{C}$, while it reaches $34000 \mathrm{r} / \mathrm{min}$ at inlet temperature $130^{\circ} \mathrm{C}$. The expansion power increases gently when the turbine rotational speed is below its optimum speed, while it increases significantly when the speed is over the optimum one. Fig. 11 indicates the effects of the turbine rotational speed on electric power and electromechanical efficiency of the system, both of them gradually increase with the rotational speed. The electromechanical efficiency increases from $42 \%$ to $65 \%$ approximately when the rotational speed changes from $20000 \mathrm{r} / \mathrm{min}$ to $50000 \mathrm{r} / \mathrm{min}$. It is found that the electromechanical efficiency decreases with the turbine inlet temperature. The maximum electric power of the system is $1.884 \mathrm{~kW}$ at the inlet temperature of $130^{\circ} \mathrm{C}$ and the rotational speed of $53564 \mathrm{r} / \mathrm{min}$.

\subsection{Effects of cooling water flow rate}

Fig. 12 shows the effects of cooling water flow rate (cold source) on the turbine outlet pressure at a fixed turbine inlet temperature. The heat transfer capacity of the condenser increases with the cooling water flow rate, the pressure at the condenser inlet gradually drops as well, accordingly, the turbine outlet pressure decreases and its pressure ratio increases. Figure 13 shows the influences of cooling water flow rate on the radial turbine performance. The temperature of the cooling water is $15.4^{\circ} \mathrm{C}$ at the condenser inlet. The rotational speed of the turbine is increased by enhancing the flow rate of cooling water. The turbine output power is also increased with the flow rate, this is due to the fact that the back pressure of the radial turbine is reduced and the pressure ratio is enlarged.

\section{Conclusions}


The experiments are conducted on an organic Rankine cycle system with a radial inflow turbine and R123. The evaporator outlet temperature and pressure, turbine outlet pressure, inlet superheat as well as the condenser outlet pressure increase with heat source temperature under the constant flow rate condition. When heat source temperature is constant, the evaporator outlet pressure and turbine rotational speed increase with the flow rate of the working fluid. The turbine output power, electric power, and electromechanical efficiency increase with the flow rate of the working fluid as well. The maximum values of enthalpy and temperature drops and electric power are $13.7 \mathrm{~kJ} / \mathrm{kg}, 22^{\circ} \mathrm{C}$, and $1.884 \mathrm{~kW}$, respectively.

There is an optimum rotational speed for the radial turbine in the system at which the maximum isentropic efficiency is achieved, and a further increase in the rotational speed results in a noticeable decline in isentropic efficiency. The optimum rotational speed increases with the heat source temperature. The maximum isentropic efficiency is $83.6 \%$ when the rational speed is about $34000 \mathrm{r} / \mathrm{m}$ at the turbine inlet temperature $130^{\circ} \mathrm{C}$.

The condenser inlet pressure drops with the flow rate of cooling water when both the heat source temperature and flow rate of the working fluid are constant, the pressure ratio of the radial turbine increases, and the turbine output power increases as well. The system pressure drop and thermal efficiency increase with the flow rate of the working fluid. In this study, the maximum thermal efficiency is $5.7 \%$. 


\begin{tabular}{|c|c|c|c|}
\hline \multicolumn{4}{|c|}{ Nomenclature } \\
\hline \multicolumn{2}{|c|}{ Symbol } & PIT & pressure at turbine inlet $(\mathrm{MPa})$ \\
\hline $\mathrm{h}$ & enthalpy $\left(\mathrm{kJ} \mathrm{kg}^{-1}\right)$ & POT & pressure at turbine outlet (MPa) \\
\hline$q_{\mathrm{m}}$ & mass flow rate of working fluid $\left(\mathrm{kg} \mathrm{s}^{-1}\right)$ & TIS & superheat at turbine inlet $\left({ }^{\circ} \mathrm{C}\right)$ \\
\hline Q & heat $(\mathrm{W})$ & POC & pressure at condenser outlet (MPa) \\
\hline $\mathrm{T}$ & temperature $\left({ }^{\circ} \mathrm{C}\right)$ & WFR & mass flow rate of water $(\mathrm{kg} / \mathrm{s})$ \\
\hline$W_{\mathrm{P}}$ & work done by pump (W) & & \\
\hline$W_{\mathrm{T}}$ & turbine power $(\mathrm{W})$ & \multicolumn{2}{|c|}{ Subscripts } \\
\hline$W_{\mathrm{T}, \mathrm{S}}$ & isentropic turbine power $(\mathrm{W})$ & $\mathrm{p}$ & pump \\
\hline$h_{4 \mathrm{~s}}$ & isentropic enthalpy at turbine outlet (W) & $\mathrm{T}$ & turbine \\
\hline$P_{\mathrm{e}}$ & electric power $(\mathrm{W})$ & $\mathrm{m}$ & mass flow \\
\hline$\eta_{\mathrm{s}}$ & isentropic efficiency of turbine (\%) & $\mathrm{s}$ & isentropic \\
\hline$\eta_{\mathrm{M}}$ & electromechanical efficiency (\%) & $\mathrm{e}$ & electric \\
\hline$\eta_{\mathrm{t}}$ & thermal efficiency of the system (\%) & M & electromechanical \\
\hline POE & pressure at evaporator outlet (MPa) & $\mathrm{t}$ & thermal \\
\hline TOE & temperature at evaporator outlet $\left({ }^{\circ} \mathrm{C}\right)$ & & \\
\hline
\end{tabular}

\section{Acknowledgements}

Part of the work presented in this paper has received funding from the Scientific and Technological Planning Projects of Henan Province, China (No.162102310504). A part of this work was supported by the Foundation of State Key Laboratory of Coal Combustion ( No.FSKLCC1410). The financial support is gratefully acknowledged.

\section{References}

[1] W. Gu, Y. W. Weng, Y. J. Wang, S. L. Weng, Thermodynamic analysis of power generation system based on closed organic rankine cycle (ORC), J. Acta Energiae 
Solaris Sinica. 29 (2008) 608-612.

[2] C. Somayaji, First and second law analysis of organic Rankine cycle, D. USA: Mississippi State University(2008).

[3] C. Casci, G. Angelino, P. Ferrari, M. Gaia, G. Giglioli, E. Macchi, Experimental results and economics of a small $(40 \mathrm{~kW})$ organic Rankine engine. In: Int. $15^{\text {th }}$ intersociety energy conversion engineering conference, Seattle, Washington; August 1980. p. 1008-14.

[4] D. Kim and Y. Kim, Preliminary design and performance analysis of a radial inflow turbine for organic Rankine cycles, J. Appl Therm Eng. 120(2017) 549-559.

[5] Y. Li and X. D. Ren, Investigation of the organic Rankine cycle (ORC) system and the radial-inflow turbine design, J. Appl Therm Eng. 96(2016) 547-554.

[6] L. S. Pan and H. X. Wang, Improved analysis of Organic Rankine Cycle based on radial flow turbine, J. Appl Therm Eng. 61(2013) 606-615.

[7] A. W. Costall, A. G. Hernandez, P. J. Newton, R. F. Martinez-Botas, Design methodology for radial turbo expanders in mobile organic Rankine cycle applications, J. Appl Energ. 157(2015) 729-743.

[8] D. Fiaschi, G. Manfrida, F. Maraschiello, Thermo-fluid dynamics preliminary design of turbo-expanders for ORC cycles, J. Appl Energ. 97(2012) 601-608.

[9] R. Capata and G. Hernandez, Preliminary Design and Simulation of a Turbo Expander for Small Rated Power Organic Rankine Cycle (ORC), J. Energies. 7(2014) 7067-7093.

[10] C. Ricardo, A. B. José, J. B. Maria, M. M. José, A Humid Air Turbine-Organic Rankine Cycle combined cycle for distributed micro generation, J. Energ Convers Manage.104(2015) 115-126.

[11] M. Q. Li, J. F. Wang, W. F. He, L. Gao, B. Wang, S. L. Ma, Y. P. Dai, Construction and preliminary test of a low-temperature regenerative organic Rankine cycle (ORC) using R123, J. Renew Energ. 57(2013) 216-222.

[12] X. D. Wang, L. Zhao, J. L. Wang, Experimental investigation on the low-temperature solar Rankine cycle system using R245fa, J. Energ Convers Manage. 52(2011) 946-952. 
[13] X. D. Wang, L. Zhao, J. L. Wang, W. Z. Zhang, X. Z. Zhao, W. Wu, Performance evaluation of a low-temperature solar Rankine cycle system utilizing R245fa, J. Sol Energy. 84(2010) 353-364.

[14] T. Yamamoto, T. Furuhata, N. Arai, K. Mori, Design and testing of the organic Rankine cycle, J. Energy. 26(2001) 239-251.

[15] S. H. Kang, Design and experimental study of ORC (organic Rankine cycle) and radial turbine using R245fa working fluid, J. Energy. 41(2012) 514-524.

[16] D. Fiaschi, G. Manfrida, F. Maraschiello, Design and performance prediction of radial ORC turboexpanders, J. Appl Energ. 138(2015) 517-532.

[17] D. H. Wei, X. H. Lu, Z. Lu, J. M. Gu, Performance analysis and optimization of organic Rankine cycle(ORC) for waste heat recovery, J. Energ Convers Manage. 48(2007) 1113-1119. 
Table 1

Size parameters of the radial turbine.

\begin{tabular}{cc}
\hline Parameters & Values \\
\hline inlet diameter of impeller & $50 \mathrm{~mm}$ \\
outlet inner diameter of impeller & $34 \mathrm{~mm}$ \\
outlet outer diameter of impeller & $19 \mathrm{~mm}$ \\
number of impeller blades & 12 \\
outer diameter of nozzle & $70 \mathrm{~mm}$ \\
inner diameter of nozzle & $56 \mathrm{~mm}$ \\
number of static-blade & 17 \\
\hline
\end{tabular}

Table 2 
Parameters of testing instruments.

\begin{tabular}{|c|c|c|c|}
\hline Parameters & Instrument & Accuracy & Company \\
\hline pressure & $\begin{array}{c}\text { pressure transducer } \\
\text { HX-L61 }\end{array}$ & $\pm 0.2 \%$ & China Star \\
\hline temperature & $\begin{array}{l}\text { thermal resistance } \\
\text { WZP Pt100 }\end{array}$ & $\pm(0.15+0.002 \mathrm{t})^{\circ} \mathrm{C}$ & \\
\hline mass flow rate & $\begin{array}{c}\text { ROTEMASS } \\
\text { RCCT34 }\end{array}$ & $\pm 0.1 \%$ & $\begin{array}{c}\text { German ROTE } \\
\text { MASS }\end{array}$ \\
\hline $\begin{array}{l}\text { water mass flow } \\
\text { rate }\end{array}$ & YK-LWGY-25 & $\pm 0.5 \%$ & Dalian Yoke \\
\hline above parameters & Agilent 34980A & 一 & USA Agilent \\
\hline frequency & $\begin{array}{l}\text { clamp sensors } \\
\text { CT9693-10 }\end{array}$ & $\pm 0.1 \%$ & HIOKI E.E \\
\hline power & power meter $8903 \mathrm{D}$ & $\pm 0.5 \%$ & China QingZhi \\
\hline
\end{tabular}

Table 3 
Parameters of the experimental program.

\begin{tabular}{cc}
\hline Parameters & Values \\
\hline POE & $0.20-0.48 \mathrm{MPa}$ \\
TOE & $110,115,120,125,130,135,140^{\circ} \mathrm{C}$ \\
PIT & $0.22-0.44 \mathrm{MPa}$ \\
POT & $0.15-0.20 \mathrm{MPa}$ \\
TIS & $34-78^{\circ} \mathrm{C}$ \\
POC & $0.15-0.18 \mathrm{MPa}$ \\
WFR & $0.27-1.11 \mathrm{~kg} / \mathrm{s}$ \\
temperature drop in turbine & $9-22^{\circ} \mathrm{C}$ \\
enthalpy drop in turbine & $6.3-13.7 \mathrm{~kJ} / \mathrm{kg}$ \\
system pressure difference & $0.07-0.28 \mathrm{MPa}$ \\
Turbine rotate speed & $20000-54000 \mathrm{r} / \mathrm{min}$ \\
\hline
\end{tabular}

Note: POE means Pressure of working fluid at the evaporator outlet; TOE means Temperature of working fluid at the evaporator outlet; PIT means Pressure of working fluid at the turbine inlet; POT means Pressure of working fluid at the turbine outlet; TIS means superheat of working fluid at the turbine inlet; POC means Pressure of working fluid at the condenser outlet; WFR means Mass flow rate of water.

List of Figures 


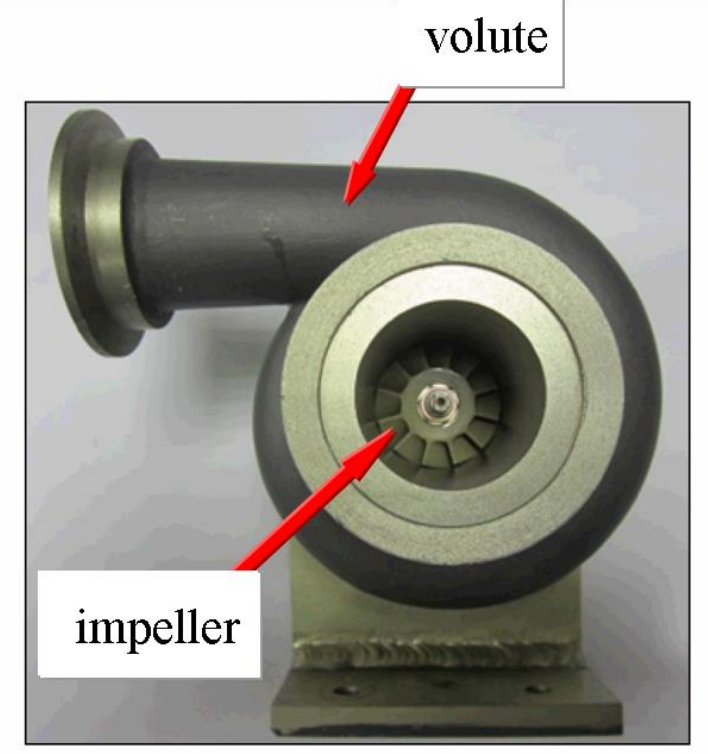

(a). radial turbine

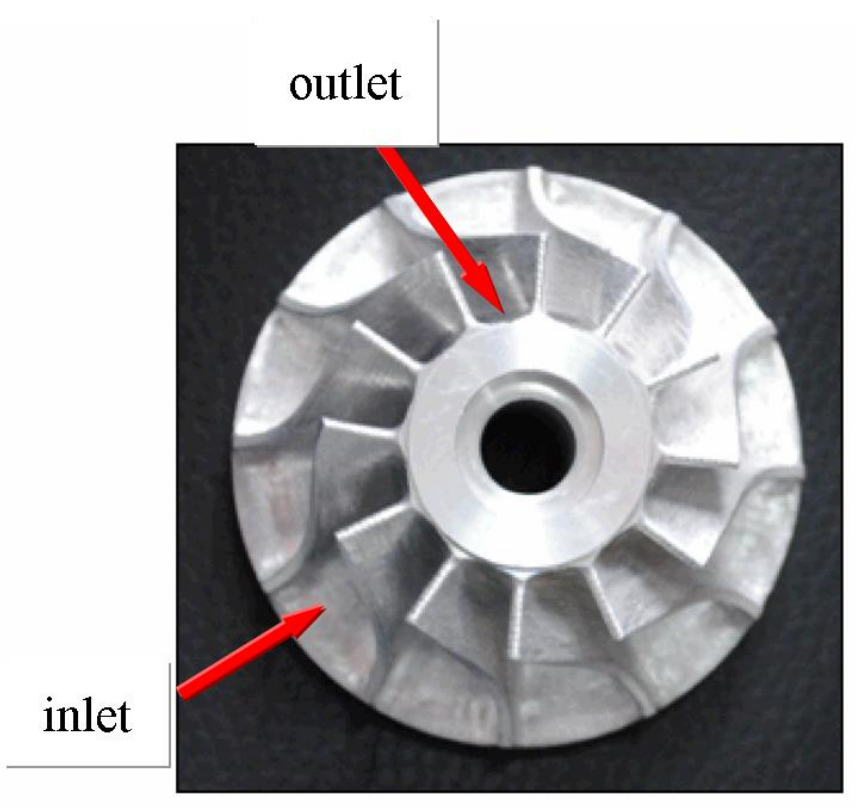

(b). impeller 


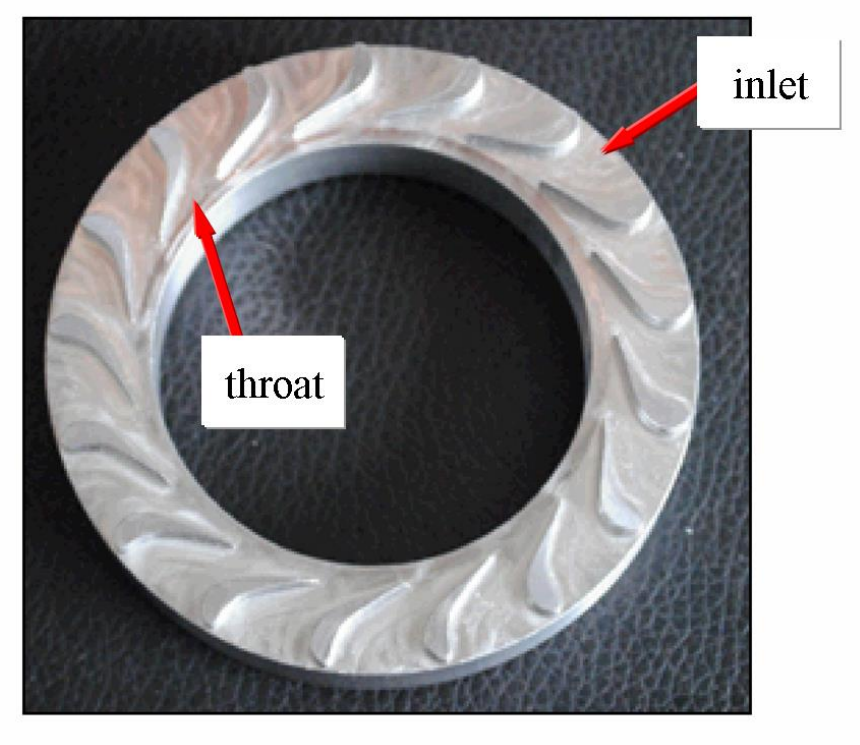

(c). nozzle

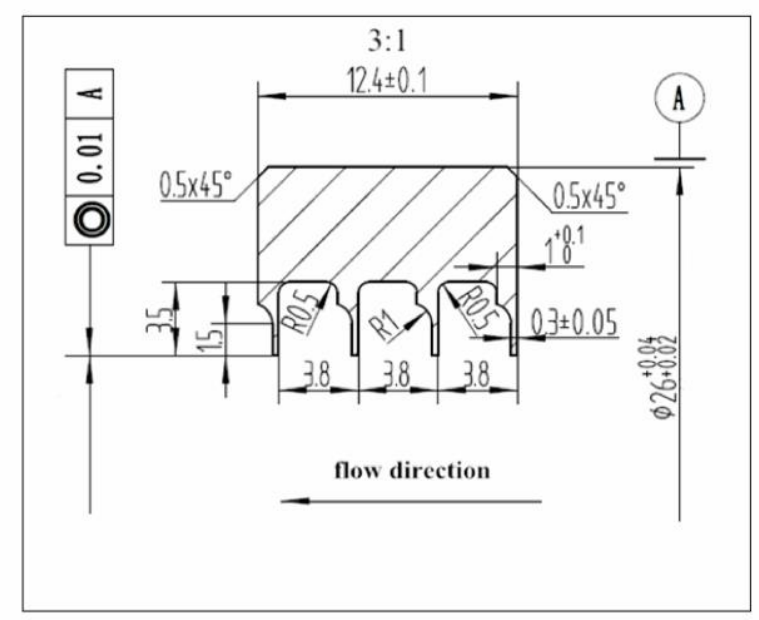

(d). labyrinth seal

Fig. 1. Photograph of the radial turbine and schematic diagram of the labyrinth seal. 


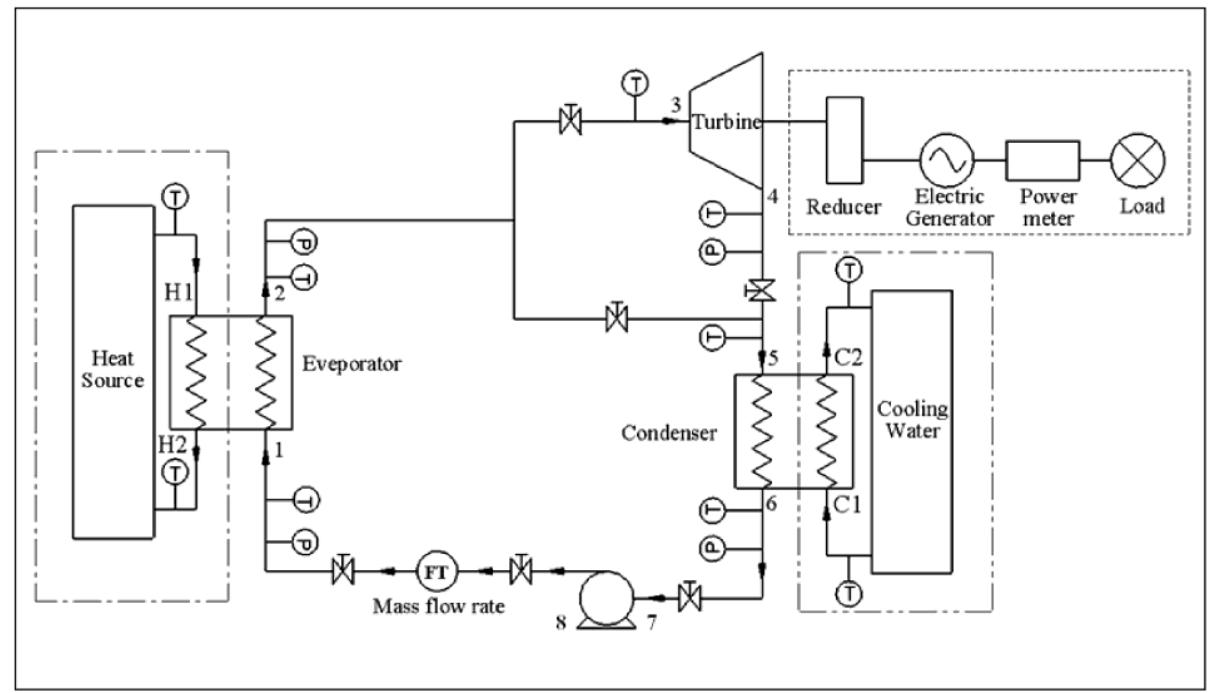

Fig. 2. Schematic diagram of the designed ORC system. 


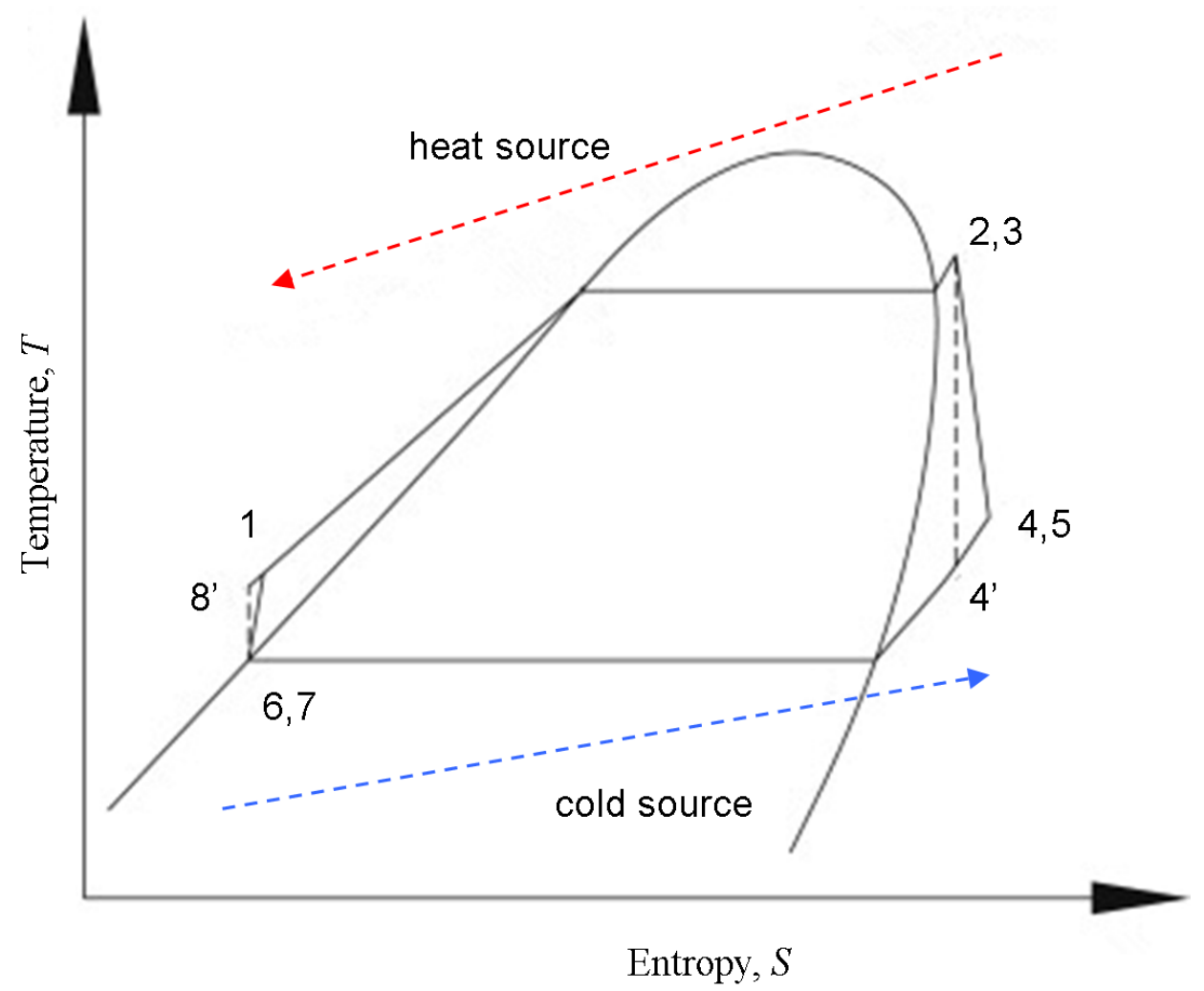

Fig. 3. $T-S$ diagram of a basic ORC system 


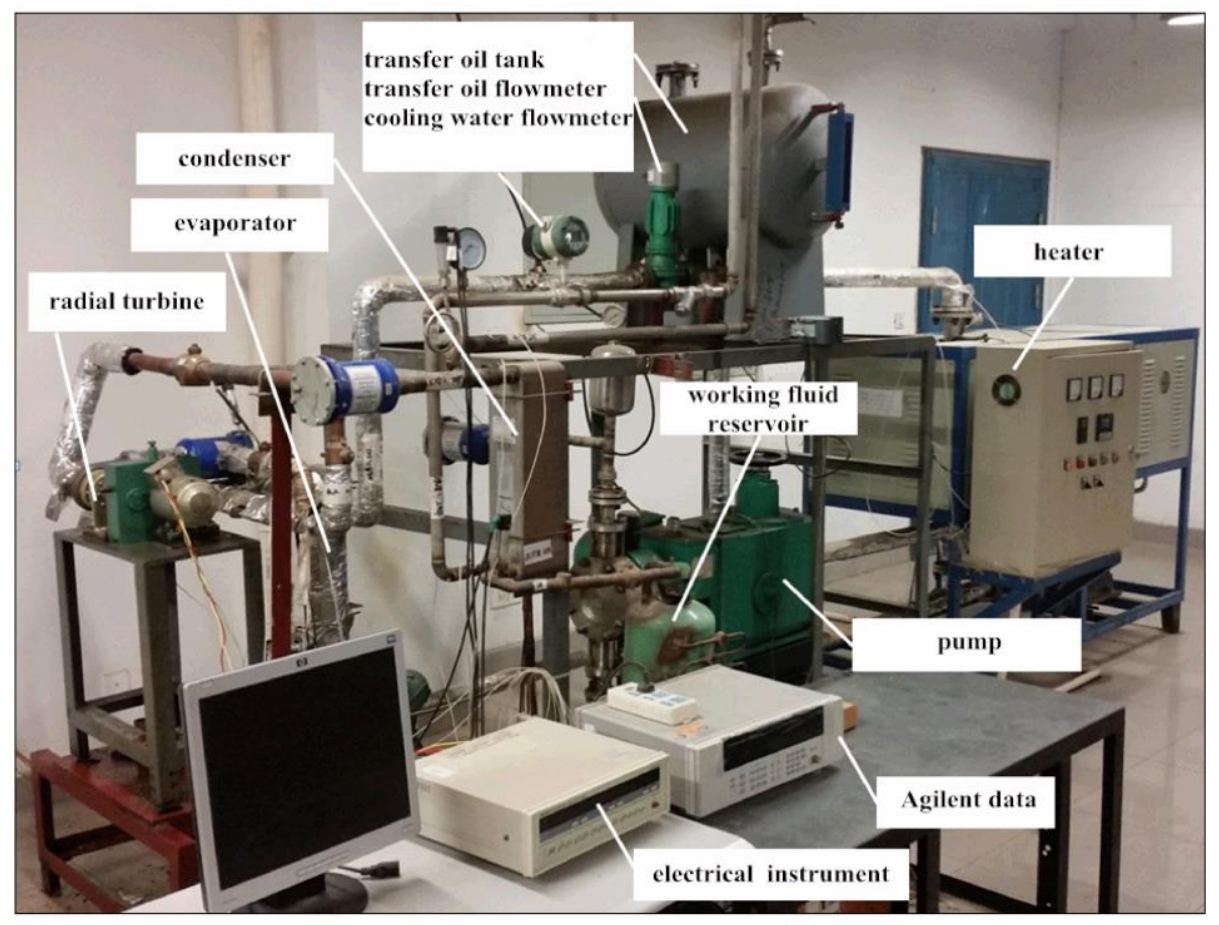

Fig. 4. Schematic diagram of the designed ORC system. 


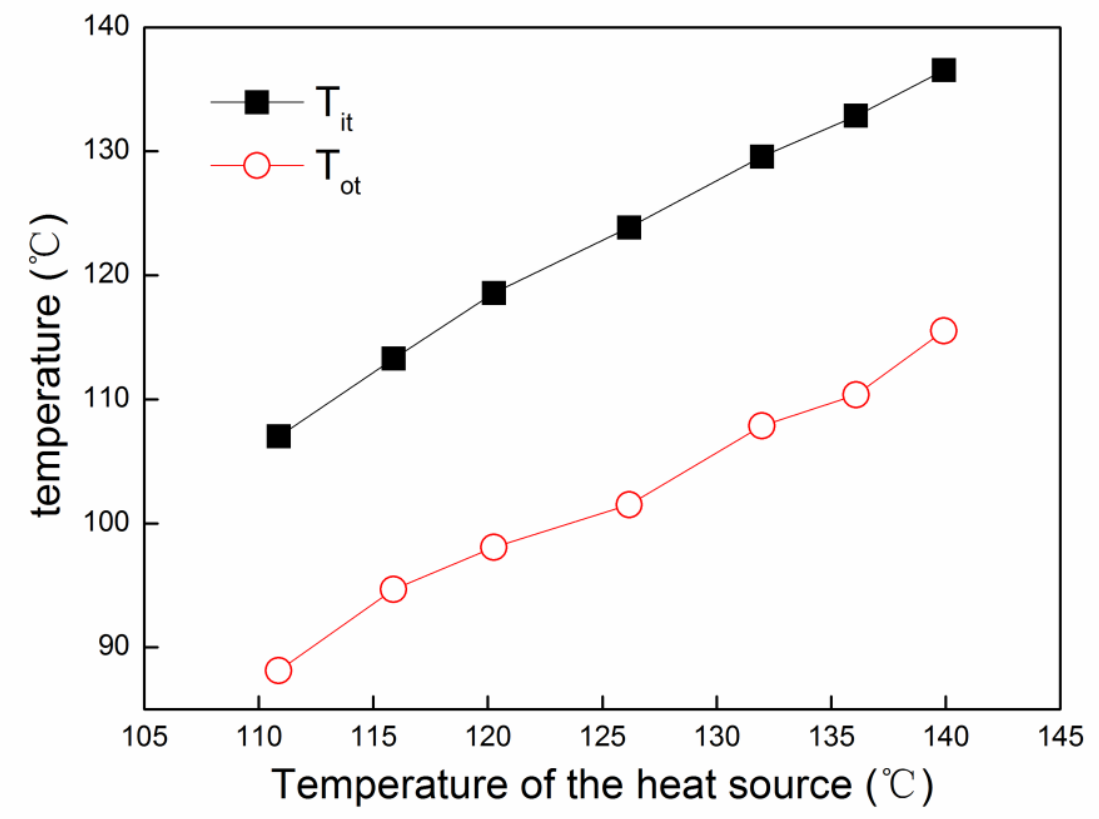

Fig. 5. Variations of inlet temperature $\mathrm{T}_{\mathrm{it}}$ and outlet temperature $\mathrm{T}_{\mathrm{ot}}$. With heat source temperature 


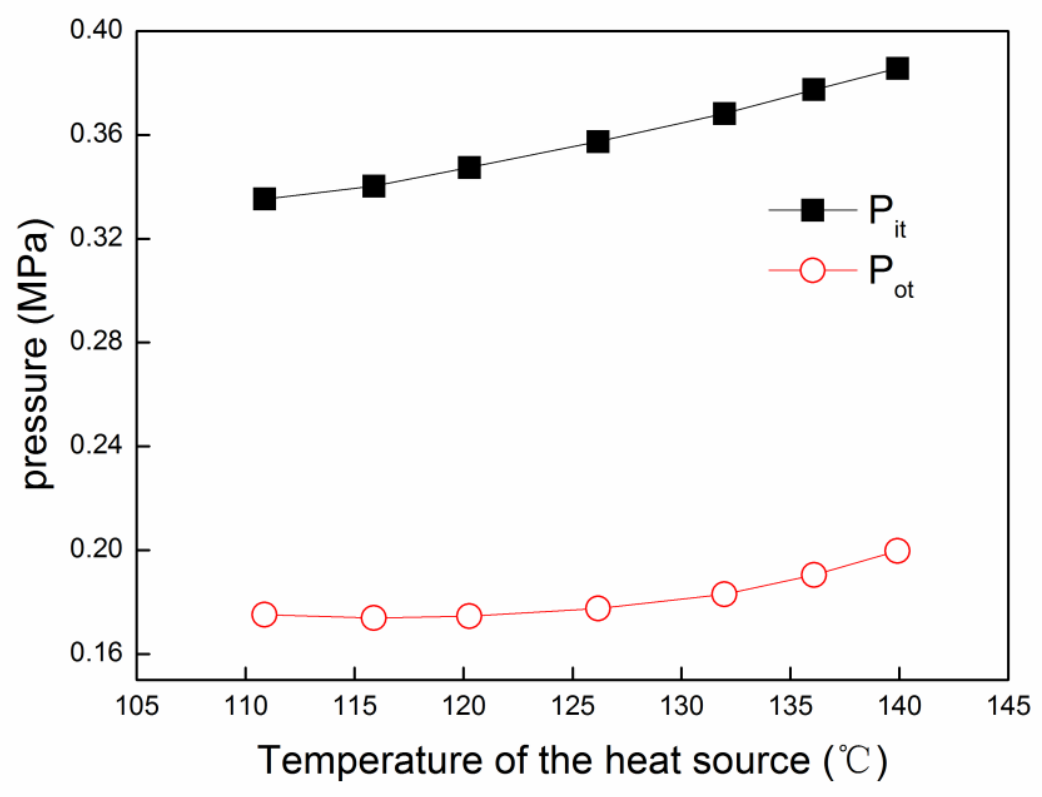

Fig. 6. Variations of inlet pressure $\mathrm{P}_{\mathrm{it}}$ and outlet pressure $\mathrm{P}_{\mathrm{ot}}$ with heat source temperature 


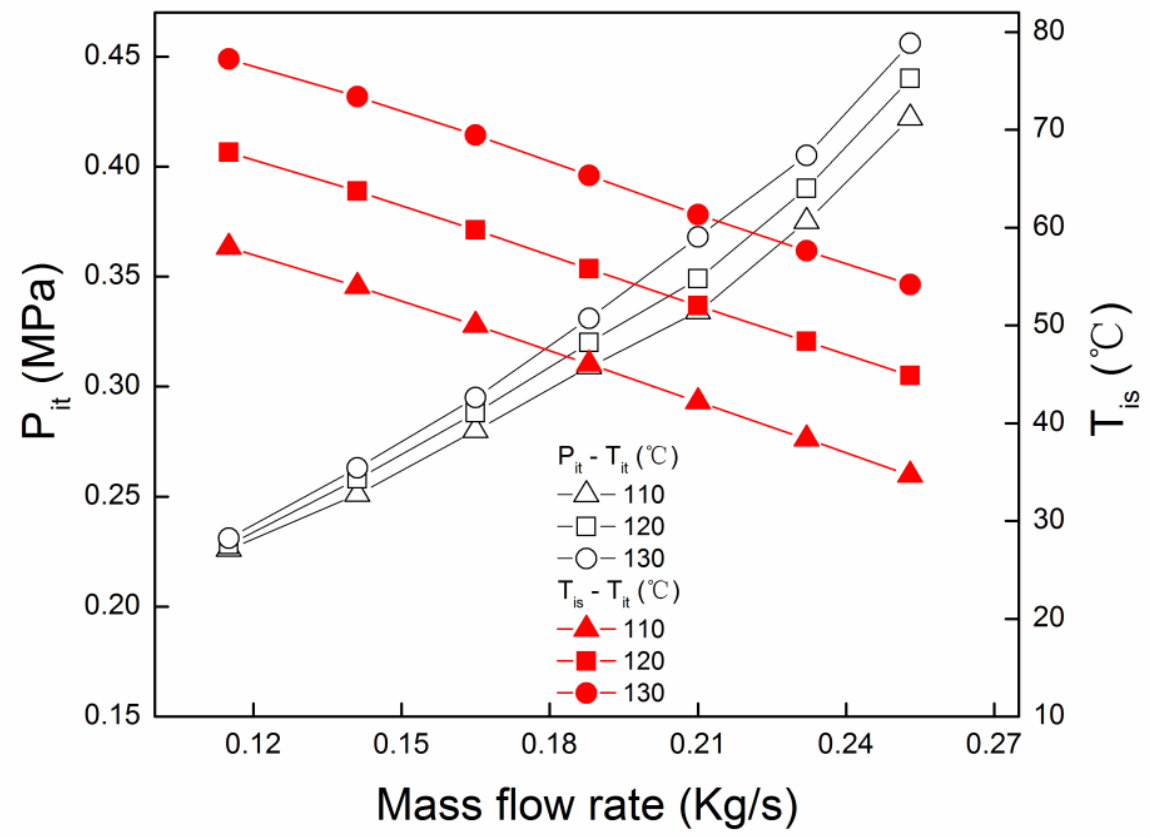

Fig. 7. Variations of inlet pressure $P_{i t}$ and superheat temperature $T_{\text {is }}$ with mass flow rate 


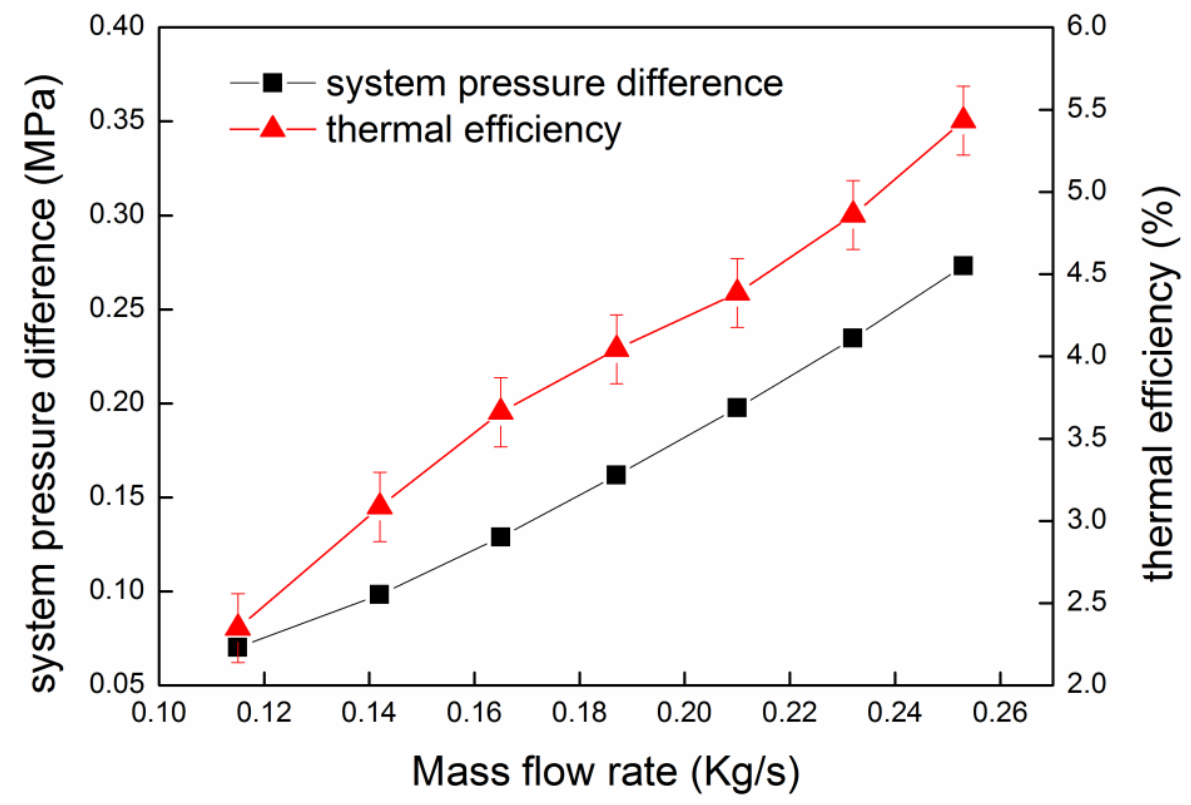

Fig. 8. Variations of system pressure difference and thermal efficiency with mass flow rate 


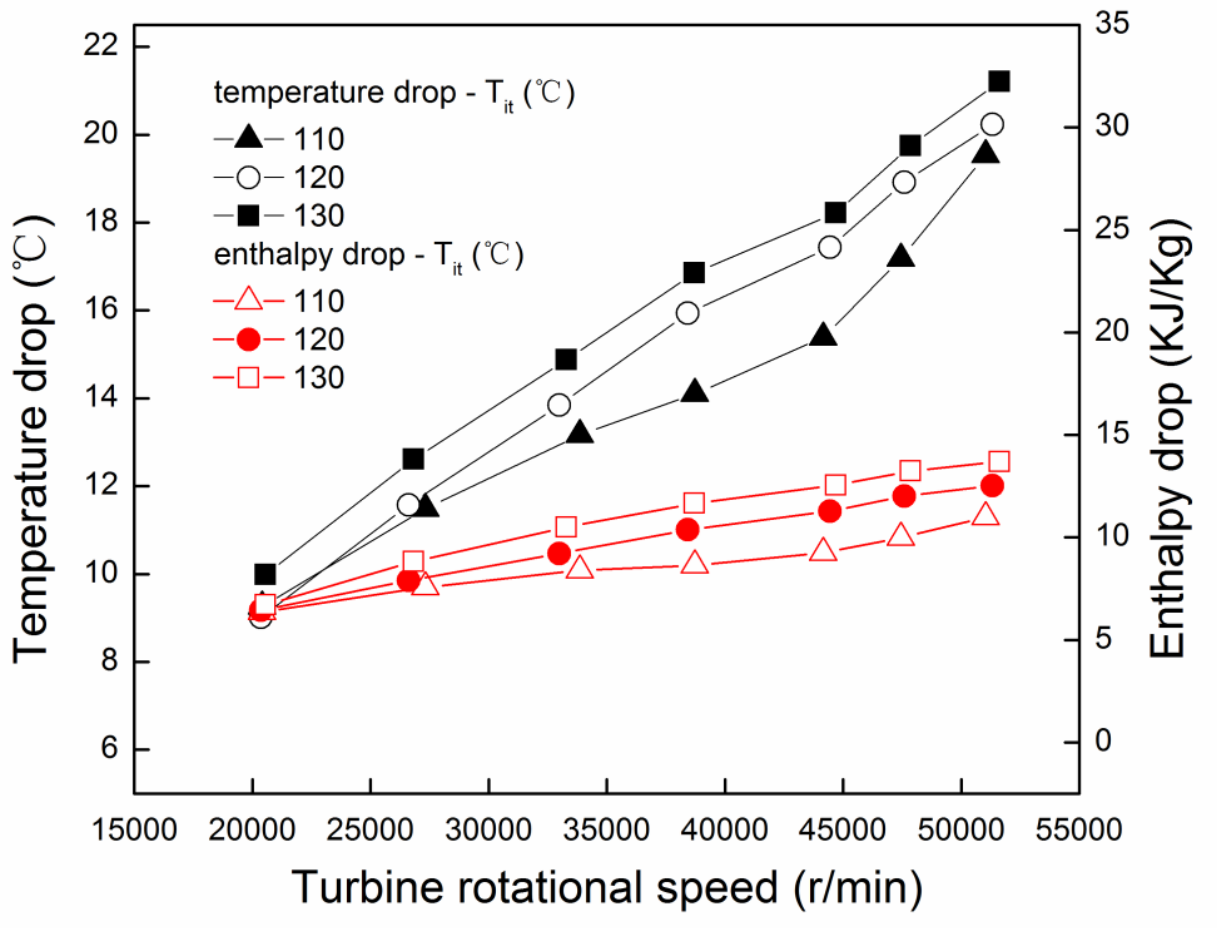

Fig. 9. Variations of temperature and enthalpy drop with turbine rotational speed 


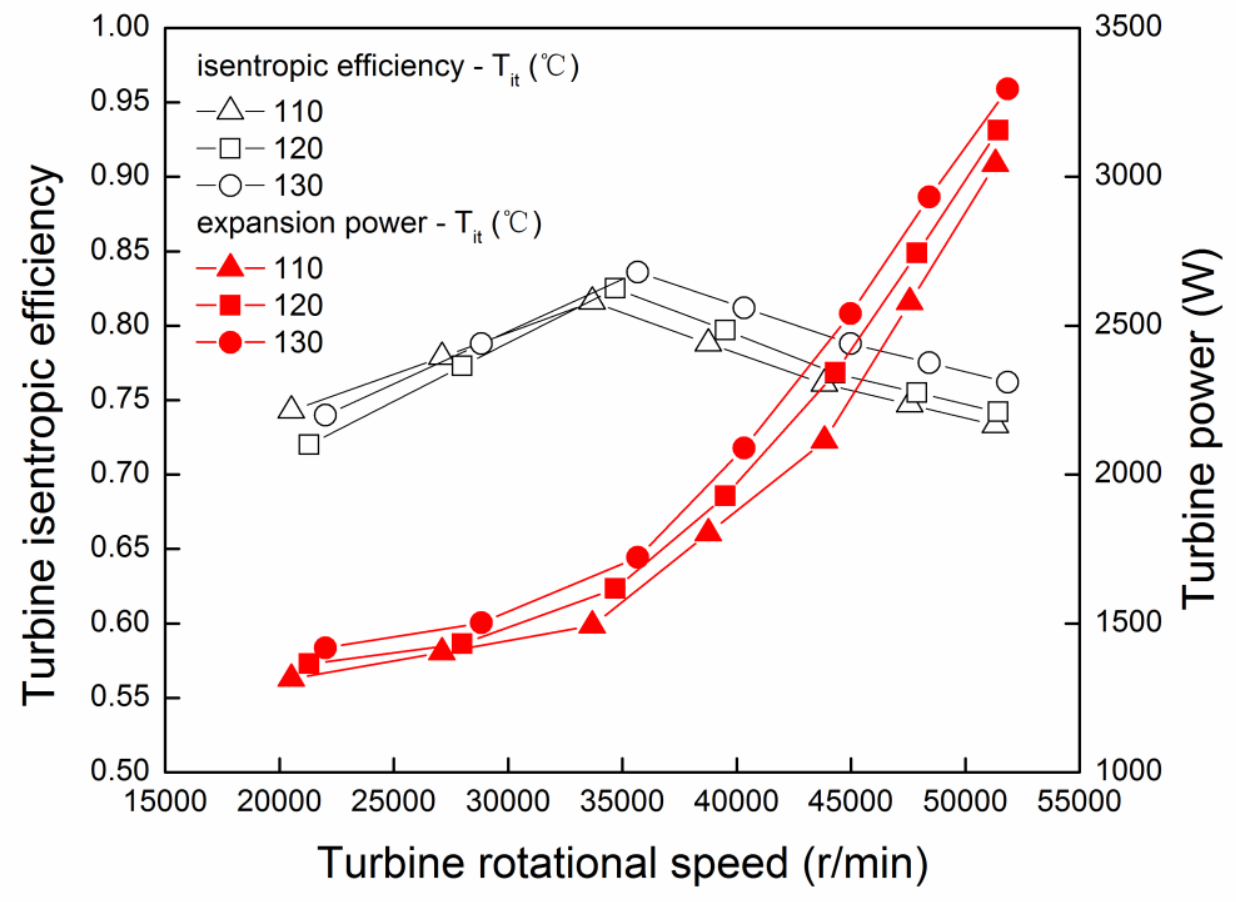

Fig. 10. Variations of isentropic efficiency and turbine power with turbine rotational speed 


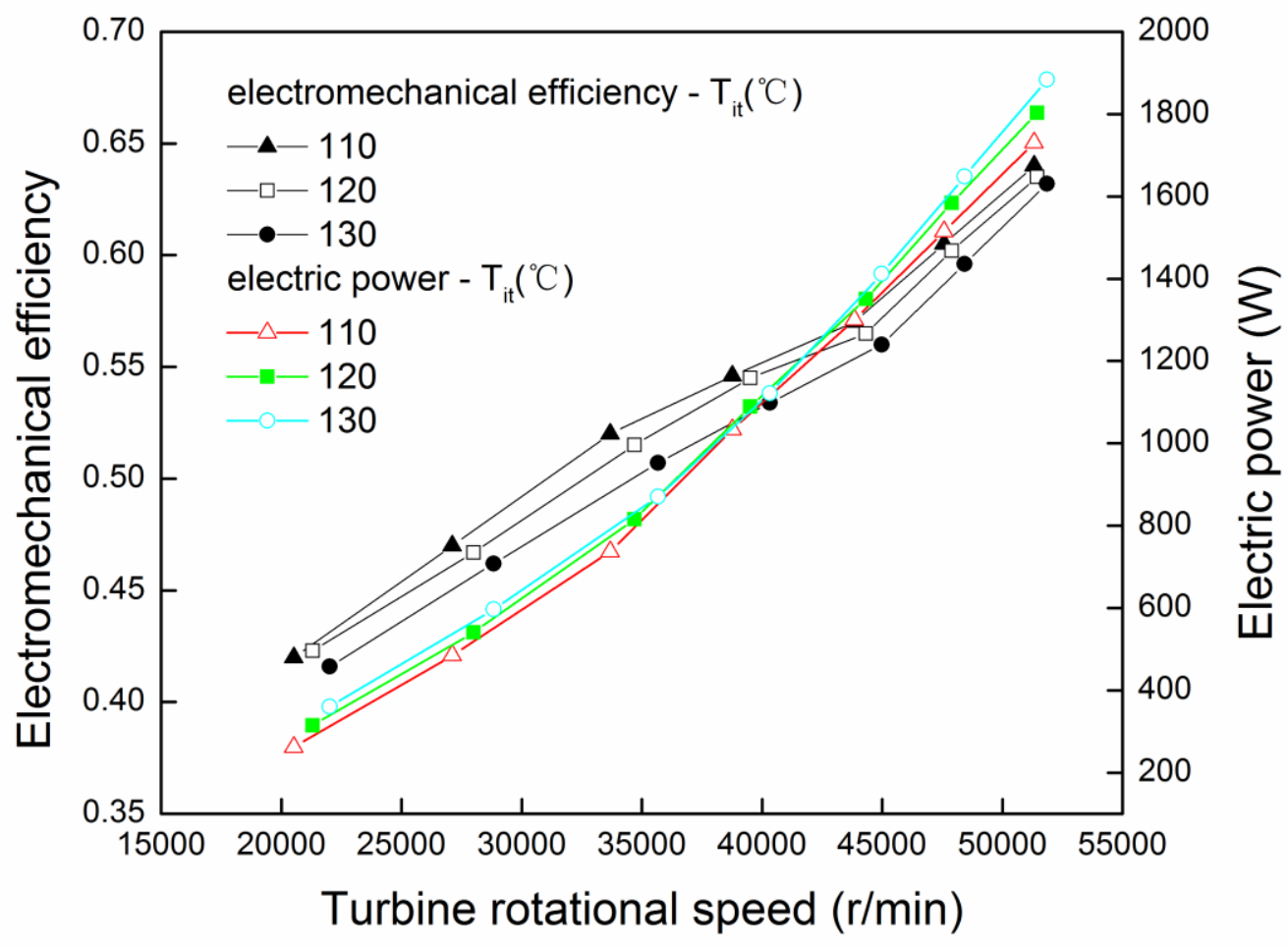

Figure. 11. Variations of electromechanical efficiency and electric power with turbine rotational speed 


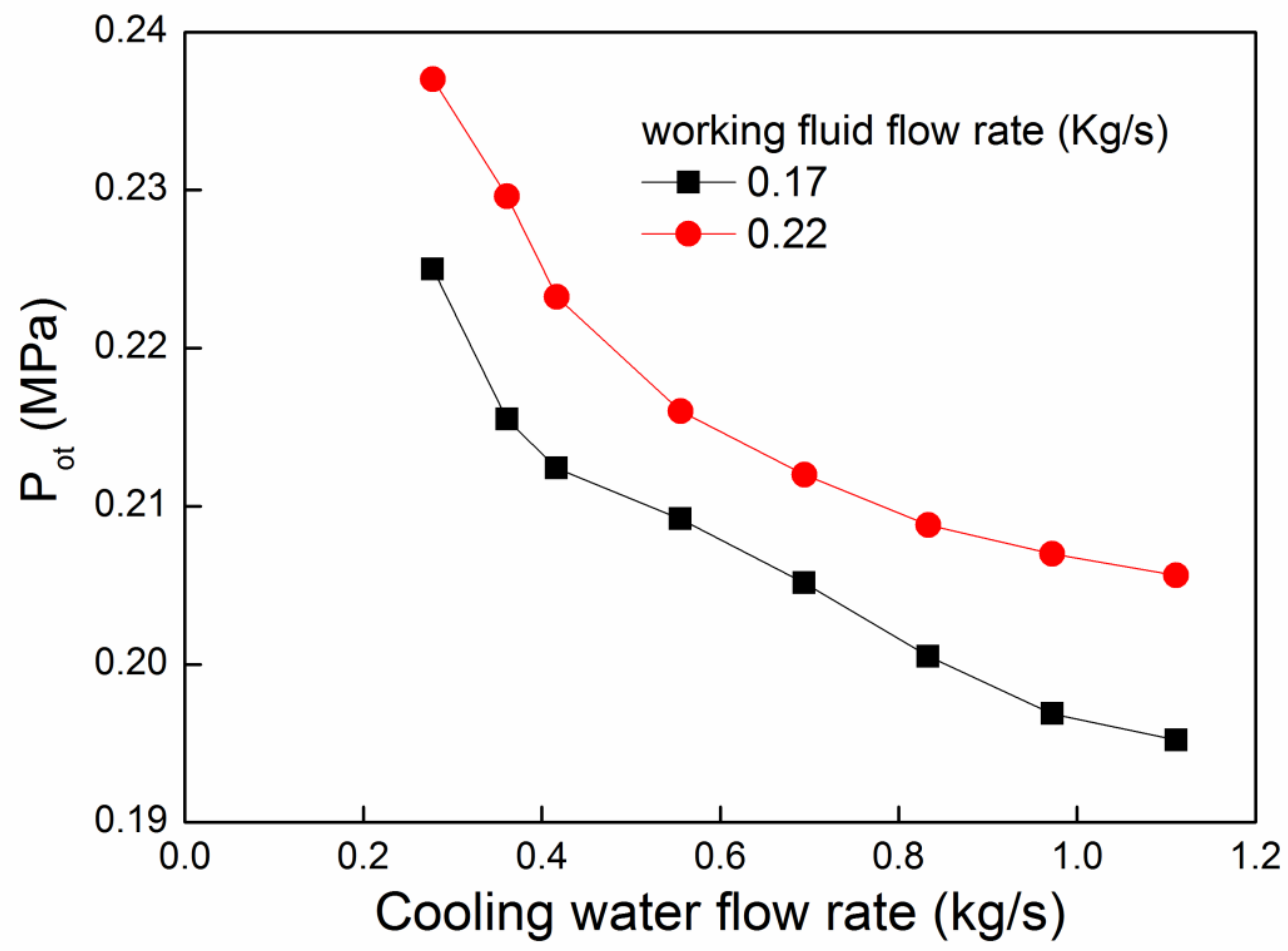

Fig. 12. Variation of turbine outlet pressure $\mathrm{P}_{\mathrm{ot}}$ with cooling water flow rate 


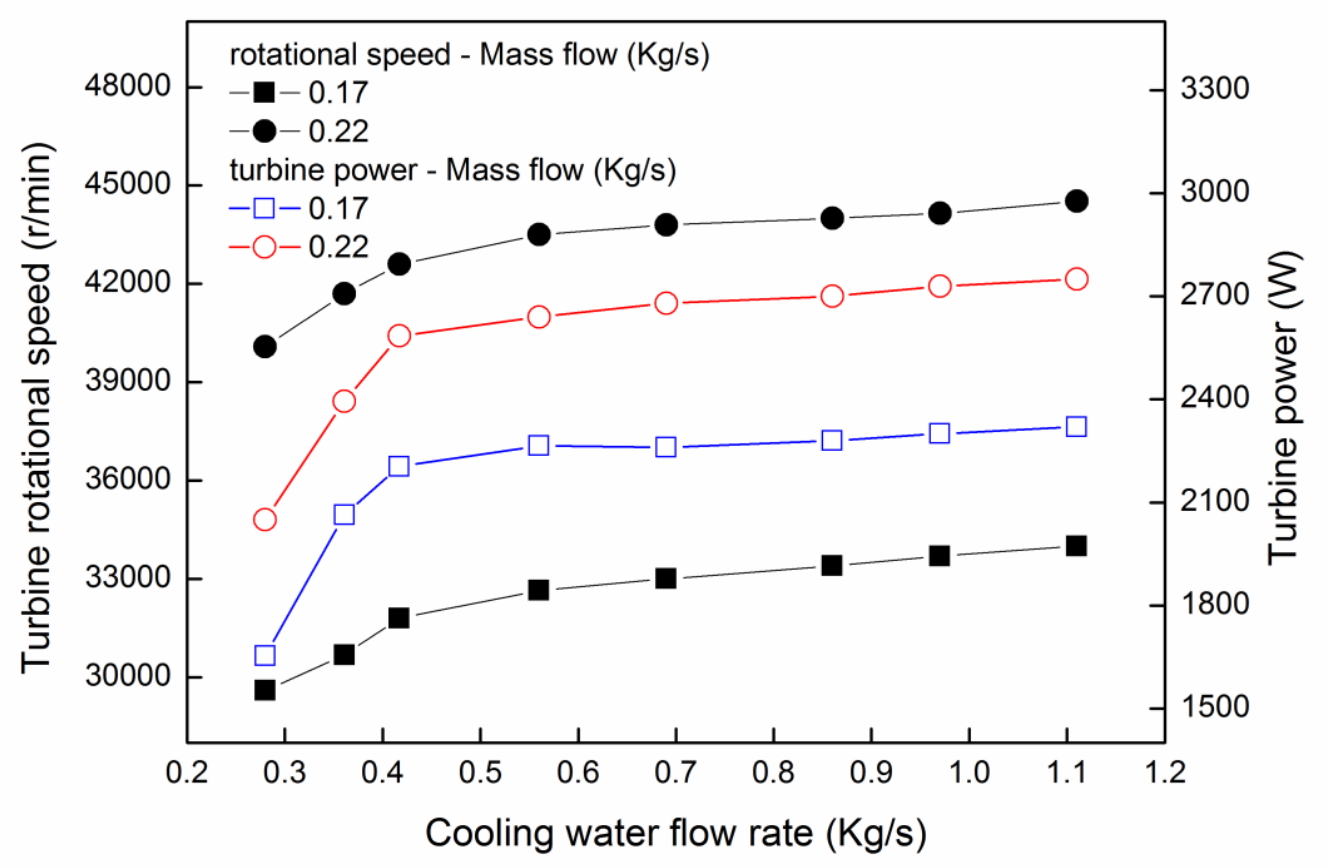

Fig. 13. Variations of rotational speed and turbine power with cooling water flow rate 


\section{HIGHLIGHTS}

- The design method of a small radial inflow turbine is introduced.

- Effect of turbine rotational speed on turbine isentropic efficiency is clarified.

- Effects of the cooling water on system performance parameters are analyzed. 